\title{
IGF-I and IGF-II Protect Cultured Hippocampal and Septal Neurons against Calcium-mediated Hypoglycemic Damage
}

\author{
Bin Cheng and Mark P. Mattson \\ Sanders-Brown Research Center on Aging and Department of Anatomy and Neurobiology, University of Kentucky, \\ Lexington, Kentucky 40536-0230
}

Insulin and insulin-like growth factors I and II (IGF-I and IGFII) have recently been shown to have biological activity in central neurons, but their normal functions and mechanisms of action in the brain are unknown. Since central neurons are particularly vulnerable to hypoglycemia that results from ischemia or other insults, we tested the hypothesis that growth factors can protect central neurons against hypoglycemic damage in vitro. IGF-I and IGF-II (3-100 $\mathrm{ng} / \mathrm{ml})$ each prevented glucose deprivation-induced neuronal damage in a dose-dependent manner in rat hippocampal and septal cell cultures. High concentrations of insulin (greater than 1 $\mu \mathrm{g} / \mathrm{ml}$ ) also protected neurons against hypoglycemic damage. Epidermal growth factor did not protect against hypoglycemic damage. Both IGFs and insulin were effective when administered $24 \mathrm{hr}$ before or immediately following the onset of glucose deprivation. Direct measurements of intraneuronal calcium levels and manipulations of calcium influx demonstrated that calcium influx and sustained elevations in intraneuronal calcium levels mediated the hypoglycemic damage. IGF-I and IGF-II each prevented the hypoglycemiainduced elevations of intraneuronal free calcium. Studies with excitatory amino acid receptor antagonists and calcium channel blockers indicated that NMDA receptors did, and L-type calcium channels did not, play a major role in hypoglycemic damage. Taken together, these findings indicate that IGFs can stabilize neuronal calcium homeostasis and thereby protect against hypoglycemic damage.

Insulin and insulin-like growth factors I and II (IGF-I and IGFII) are closely related polypeptides that are similar in their structures and are believed to have overlapping biological functions (Rinderknecht and Humbel, 1976, 1978a,b; Humbel, 1984; Czech, 1985; Froesch et al., 1985; Rechler and Nissley, 1985; Baskin, 1987; Baskin et al., 1988; Garofalo and Rosen, 1989; Knusel et al., 1990; Sara and Hall, 1990). Insulin regulates the uptake, cellular transport, and intermediary metabolism of small nutrient molecules such as glucose, amino acids, and fatty acids in muscle and adipose tissues. Recently, insulin and IGHs (and/ or their mRNAs) have been localized in the CNS (Havrankova

\footnotetext{
Received Sept. 6, 1991; revised Nov. 19, 1991; accepted Nov. 22, 1991.

We thank S. Bose, J. Mattson, and B. Rychlik for technical help, and Drs. R. E. Rydel and J. Geddes for insightful comments on this work. This research was supported by NIH Grants NS29001 and AG05144, and the International Life Sciences Institute.

Correspondence should be addressed to Dr. Mark Mattson, Sanders-Brown Research Center on Aging, University of Kentucky, 800 South Limestone, Lexington, KY 40536-0230.

Copyright (C) 1992 Society for Neuroscience $0270-6474 / 92 / 121558-09 \$ 05.00 / 0$
}

et al., 1978; Sara et al., 1982, 1986; Rechler and Nissley, 1985; Baskin et al., 1988; Rotwein et al., 1988), suggesting that they may have biological activity in the brain. In brain cell cultures, insulin, IGF-I, and IGF-II promote neuronal survival, neurite outgrowth, and gene expression (Bhat, 1983; Lenoir and Honegger, 1983; Mill et al., 1985; Recio-Pinto et al., 1986; Aizenman and DeVellis, 1987; Kyriakis et al., 1987; Avola et al., 1988; Knusel et al., 1990; Drago et al., 1991). Insulin, IGF-I, and IGFII are each associated with a distinct cell surface receptor (Rechler and Nissley, 1985). The IGF-I receptor is structurally and functionally similar to the insulin receptor in that it possesses an $\alpha$-subunit that binds the hormone-like agent and a $\beta$-subunit that has a tyrosine-specific protein kinase (Ebina et al., 1985; Ullrich et al., 1985, 1986). The IGF-II receptor is different in structure from the IGF-I receptor or insulin receptor and appears to be identical to an intracellular mannose-6-phosphate receptor (Morgan et al., 1986, 1987).

Insulin, IGF-I, and IGF-II can be produced in cultured neurons and have been reported to occur in the brain (Binoux et al., 1981; Weyhenmeyer and Fellows, 1983; Davies et al., 1986; Ballotti et al., 1987). mRNAs for both IGFs and insulin have been detected in many brain regions (Haselbacher et al., 1985; Young, 1986; Baskin et al., 1988; Rotwein et al., 1988). There is abundant evidence for the existence of receptors for insulin and IGFs in the brain (Raizada et al., 1982, 1988; Hill et al., 1986; Burgess et al., 1987; Mendlesohn, 1987; Waldbillig and LeRoith, 1987; Bohanon et al., 1988; Lesniak et al., 1988; Garofalo and Rosen, 1989). IGF-I receptor mRNA is widely distributed in the brain, whereas insulin receptor mRNA is restricted to certain areas and appears to be coexpressed with the IGF-I receptor mRNA (Baron-Van Evercooren et al., 1991). Receptors for IGF-I and IGF-II have been found to be located in hippocampus (Lesniak et al., 1988; Araujo et al., 1989). IGFII receptor mRNA distribution in brain has not been examined.

A continuous supply of glucose is necessary for the normal functioning and survival of mammalian central neurons. Hypoglycemia results in increased utilization of endogenous substrates, depletion of ATP, membrane depolarization, extracellular accumulation of excitatory amino acids, loss of neuronal ion homeostasis, and ultimately neuronal death (Siesjo et al., 1988). Calcium normally serves physiologically important functions as a second messenger regulating neuronal plasticity (Lynch et al., 1983; Kater et al., 1988). However, excessive and sustained elevations in intracellular calcium are involved in neuronal degeneration caused by metabolic and environmental insults (Choi, 1988; Siesjo et al., 1988; Mattson, 1992). In the CNS, the excitatory neurotransmitter glutamate contributes to neuronal vulnerability to insults such as hypoglycemia and hyp- 
oxia by enhancing calcium influx (Choi, 1988). The cellular and molecular mechanisms that normally protect neurons against such insults are largely unknown. In the present study we employed hippocampal and septal cell cultures to test the hypothesis that IGFs can stabilize neuronal calcium homeostasis and protect central neurons against hypoglycemic injury.

\section{Materials and Methods}

Hippocampal and septal cultures. The hippocampal and septal culture methods employed were similar to those of Mattson and Kater (1988) and of Hartikka and Hefti (1988), respectively. Briefly, rat hippocampi and septal areas were obtained from $18 \mathrm{~d}$ Sprague-Dawley fetuses and incubated for $15 \mathrm{~min}$ in a solution of $2 \mathrm{mg} / \mathrm{mI}$ trypsin in $\mathrm{Ca}^{2+} / \mathrm{Mg}^{2+}$ free Hank's balanced salt solution buffered with $10 \mathrm{~mm}$ HEPES (HBSS; GIBCO). The hippocampi and septal areas were then rinsed once in HBSS, followed by a 5 min incubation in HBSS containing $1 \mathrm{mg} / \mathrm{ml}$ trypsin inhibitor (Sigma), and a final rinse in HBSS. Tissues were then dissociated by trituration through the narrowed bore of a fire-polished Pasteur pipette and were distributed to polylysine-coated plastic culture dishes (Corning) containing $2 \mathrm{ml}$ of Eagle's minimum essential medium (GIBCO) buffered with $10 \mathrm{~mm}$ sodium hicarbonate and supplemented $10 \%(\mathrm{v} / \mathrm{v})$ with fetal bovine serum (Sigma), $2 \mathrm{~mm} \mathrm{L-glutamine,} 20 \mathrm{~mm}$ $\mathrm{KCl}, 1 \mathrm{~mm}$ pyruvate, and $40 \mathrm{~mm}$ glucose. The culture density was $80-$ 120 cells $/ \mathrm{mm}^{2}$ of culture surface. Cultures were maintained at $37^{\circ} \mathrm{C}$ in a $6 \% \mathrm{CO}_{2} / 94 \%$ room air, humidified incubator. All experiments were done with neurons that had been in culture for 8-15 d. In some experiments, glial proliferation was halted by exposing cultures to either 10 $\mu \mathrm{M}$ cytosine arabinoside (Ara-C) or $20 \mu \mathbf{M}$ 5-fluoro-2'-deoxyuridine for 2-3 d (culture days 3-5).

Assessment of neuronal survival. Neuronal damage was assessed by our well-established morphological criteria, which correlate well with vital dye staining methods (Mattson et al., 1988). Briefly, cultures were visualized and photographed with a phase-contrast Nikon Diaphot inverted microscope. Neurons were scored as viable if they had neurites that were uniform in diameter and smooth in appearance, and somata that were smooth and round to oval in shape. In degenerating nonviable neurons, neurites were fragmented and beaded, and the soma was rough, swollen, vacuolated, and irregular in shape. Subsequent to these morphological changes, the degenerated neurons detached from the culture substrate. Viable neurons in premarked culture regions (four regions of approximately $1 \mathrm{~mm}^{2} /$ culture) were counted immediately prior to and 18-24 hr following glucose deprivation. Statistical comparisons were done using pairwise Student's $t$ tests.

Glucose deprivation and experimental treatments. Glucose deprivation was carried out by removing the culture maintenance medium and washing three times with glucose-free Locke's solution. Locke's solution contained (in $\mathrm{mm}$ ) NaCl, 154; $\mathrm{KCl}, 5.6 ; \mathrm{CaCl}_{2}, 2.3 ; \mathrm{MgCl}_{2}, 1.0 ; \mathrm{Na}$ $\mathrm{HCO}_{3}, 3.6$; and HEPES buffer, 5. Calcium-deficient medium consisted of glucose-free Locke's solution lacking added calcium. Cultures were washed thoroughly (six $2 \mathrm{ml}$ washes) with calcium-deficient Locke's immediately prior to glucose deprivation. Growth factors were prepared as 100-1000 $\times$ stocks in water and were added directly to the cultures. Cultures were pretreated with growth factor for $24 \mathrm{hr}$ prior to the onset of hypoglycemia, and the growth factors were included in the glucosefree medium during the period of hypoglycemia. Insulin (bovine) and calcitonin gene-related peptide (CGRP) were from Sigma, while IGF-I and IGF-II (human, recombinant) and epidermal growth factor (EGF; from mouse submaxillary glands) were from Boehringer Mannheim. D- $\gamma$-Glutamylglycine (DGG), DL-2-amino-5-phosphonovaleric acid (APV), 6-cyano-7-nitroquinoxaline-2,3-dione (CNQX), and 6,7-dinitroquinoxaline-2,3-dione (DNQX) were from Tocris Neuramin; these agents were prepared as stocks in Locke's solution. Nifedipine, nimodipine, verapamil, diltiazem, flunarizine, lidoflazine, and trifluoperazine (Sigma) were prepared as $20-500 \times$ stocks in dimethyl sulfoxide. Equivalent volumes of vehicle were added to control cultures and did not affect neuronal survival.

Fura-2 measurements of intraneuronal calcium levels. For these studies cells were grown in glass-bottom dishes (Mat Tek, Inc.) coated with $0.05 \%$ polyethylenimine. Intraneuronal free calcium levels were measured 14-16 hr after the onset of glucose deprivation. The procedures for fura-2 fluorescence ratio imaging were similar to those of our past work (Mattson et al., 1989). Briefly, the cells were loaded at $37^{\circ} \mathrm{C}$ for 40 min with $4 \mu \mathrm{M}$ fura-2 acetoxymethyl ester (Molecular Probes). The loaded cells were then washed two times with Locke's solution containing $2.3 \mathrm{mM} \mathrm{CaCl}$ (with or without glucose) and incubated an additional $60 \mathrm{~min}$ prior to imaging to allow deesterification of the fura2. Cells were viewed on an inverted Nikon microscope with a fluoro $40 \times$, NA 1.3 objective and an intensified CCD Camera (Quantex). A Quantex imaging system with QFM software was used to acquire and process the images. Intracellular free $\mathrm{Ca}^{2+}$ levels were determined from the ratio of the fluorescence emission using two different excitation wavelengths (350 $\mathrm{nm}$ and $380 \mathrm{~nm}$ ). Background fluorescence at each wavelength (background images were taken from regions of culture dish not containing cells) was subtracted from the cell image at that wavelength. The system was calibrated according to the procedures described by Grynkiewicz et al. (1985). Measurements were taken in neuronal cell bodies, and values represent the average free calcium level therein. Statistical comparisons were made using Student's $t$ test.

\section{Results}

$I G F-I, I G F-I I$, and insulin protect hippocampal and septal neurons against hypoglycemic damage

Incubation of rat hippocampal and septal cultures in glucosefree culture medium resulted in highly significant neuronal damage and death during $18 \mathrm{hr}$ (hippocampal) or $24 \mathrm{hr}$ (septal) exposure periods when compared with cultures maintained in medium containing 5-40 mM glucose (Fig. 1, Table 1). Approximately $85-95 \%$ of rat hippocampal and septal neurons degenerated during these glucose deprivation periods $(n=4$ 10 separate experiments for each treatment condition, 3-4 cultures/experiment). When rat hippocampal and septal cultures were pretreated for $24 \mathrm{hr}$ with $100 \mathrm{ng} / \mathrm{ml}$ of either IGF-I or IGF-II and then deprived of glucose for 18-24 hr, there was a dramatic reduction in neuronal damage compared to glucosedeprived cultures not receiving a growth factor (Fig. 1, Table 1). Neuronal survival was increased to approximately $70 \%$ in IGF-treated cultures as compared with $5-15 \%$ in the untreated glucose-deprived cultures ( $n=4-10$ separate cultures/treatment group; $p<0.001$ ). Both IGF-I and IGF-II were able to sustain hippocampal and septal neurons for up to $40 \mathrm{hr}$ in the absence of glucose ( $n=4$ separate cultures). Insulin at $100 \mathrm{ng} / \mathrm{ml} \mathrm{did}$ not protect neurons against hypoglycemic damage (Table 1). The data presented in the dose-response curve in Figure 2 demonstrate that very low concentrations of IGF-I and IGF-II (1$10 \mathrm{ng} / \mathrm{ml}$, approximately $150-1500 \mathrm{pm}$ ) can significantly protect against neuronal damage in both hippocampal and septal cultures. Insulin at concentrations up to $300 \mathrm{ng} / \mathrm{ml}$ (approximately $60 \mathrm{~nm}$ ) did not protect against hypoglycemic damage. However, higher concentrations of insulin $(1 \mu \mathrm{g} / \mathrm{ml}$ or greater) did significantly protect both hippocampal and septal neurons against hypoglycemic damage (Figs. 1, 2). EGF from 1 to $100 \mathrm{ng} / \mathrm{ml}$ failed to prevent neuronal damage after glucose deprivation. Similarly, no effects were observed with 100 nM CGRP.

Since both rat hippocampal and septal cultures contained glia (predominately type I astrocytes; cf. Mattson et al., 1988), we determined whether reducing the number of glial cells in the culture would influence the protective effects of IGFs against glucose deprivation. Glial cell proliferation was inhibited by the addition of $10 \mu \mathrm{M}$ Ara-C to the cultures (Fig. 3). Our preliminary experiments showed that adding Ara- $\mathrm{C}$ to hippocampal cultures reduced the number of astrocytes to less than $5-10 \%$ of the total cell number without significantly affecting the number of neurons. IGF-I and IGF-II were found to protect against neuronal death induced by glucose deprivation in glia-depleted cultures (Fig. 3). Similar results were obtained in septal cultures (data not shown). These data suggested that the neuroprotective actions of IGF-I and IGF-II were not mediated by glia, although 

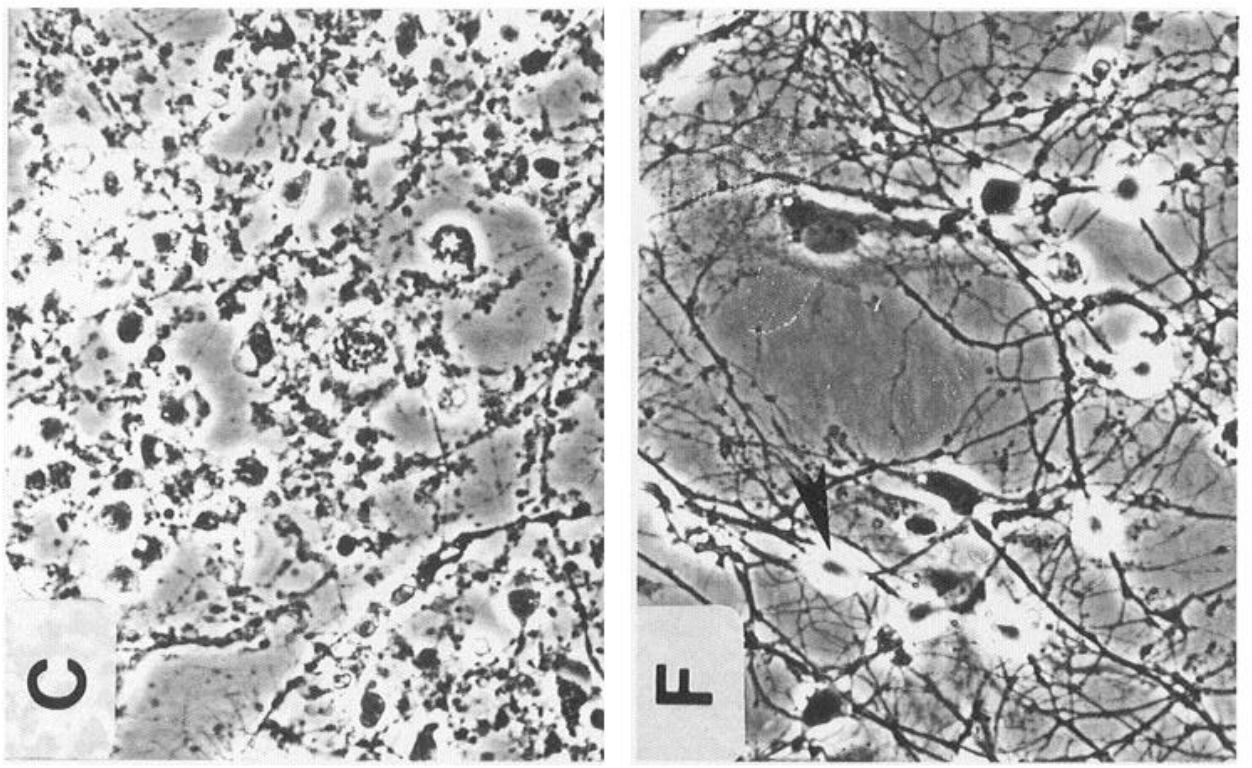

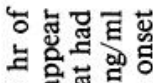

$\infty$ 我

s.

运要起

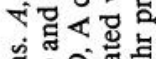

苟

政

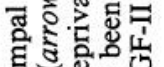

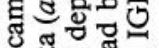

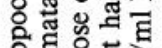

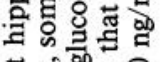

둔

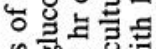

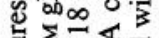

当昰证

ฮ유류

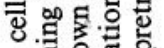

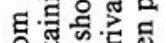

(1)

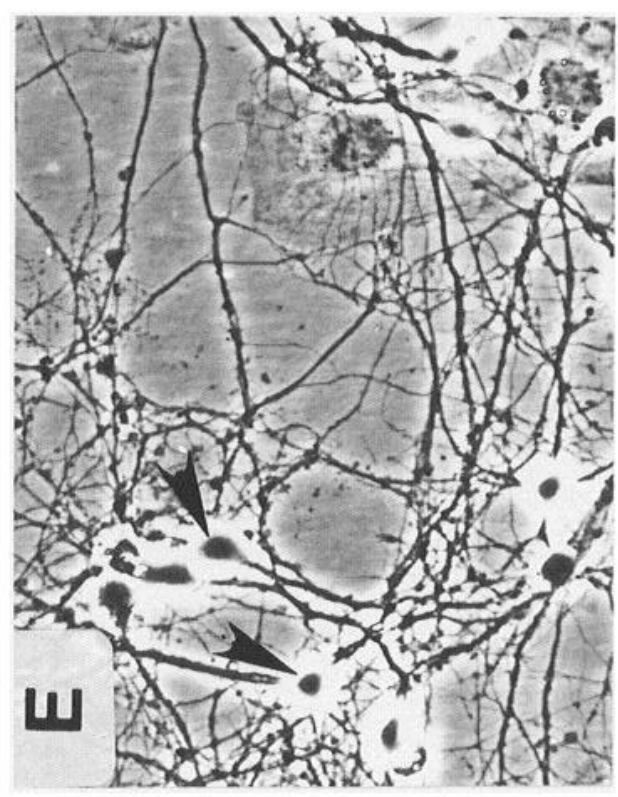

원.

空

的:

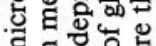

究范去

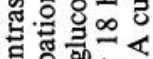

ठ규.

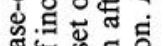

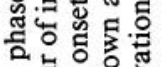

노을

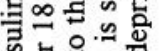

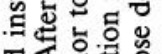

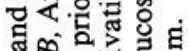

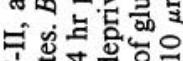

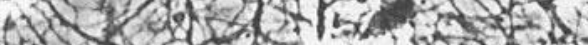

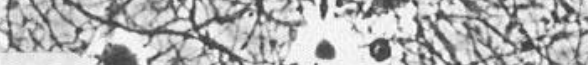

$\infty$

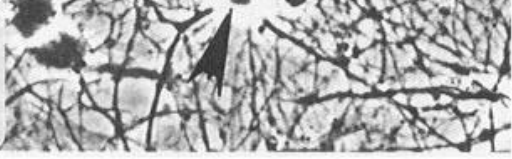

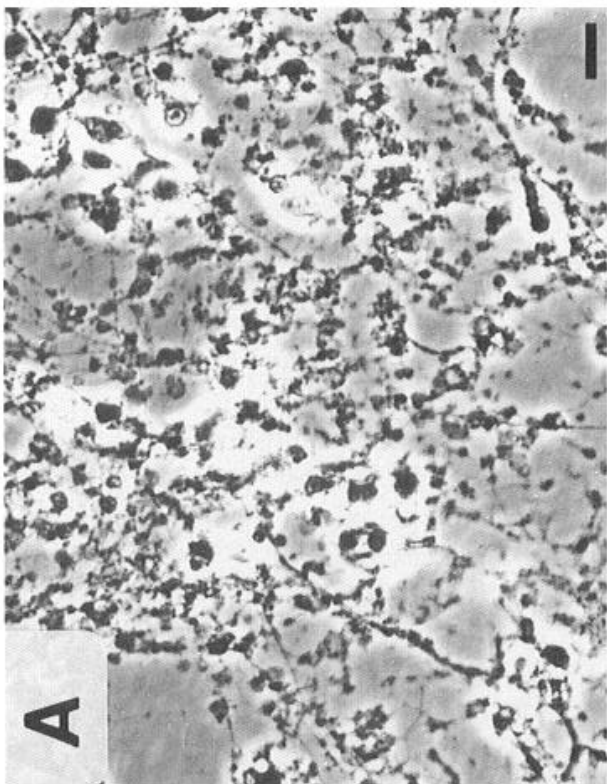

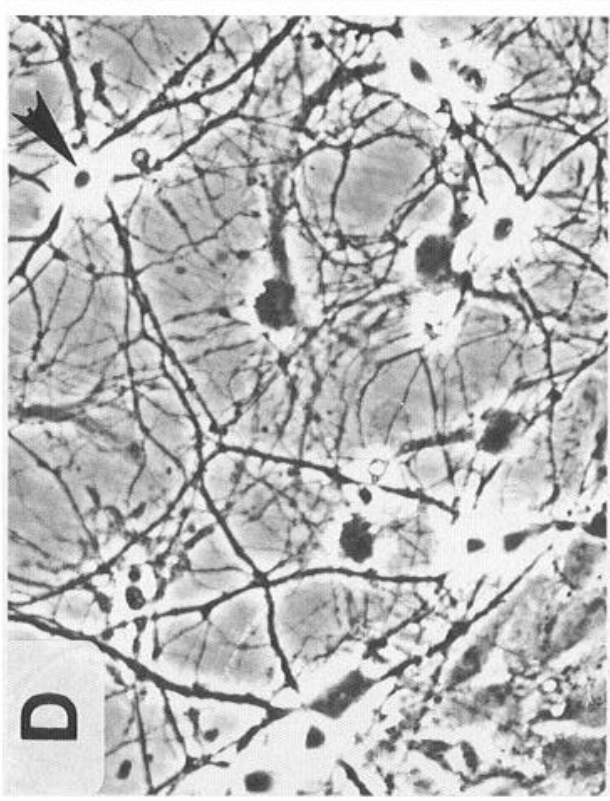

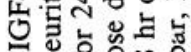

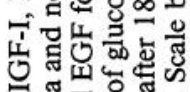

तี $\overline{\mathrm{B}}$.

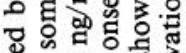

웅요연.

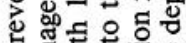

대용

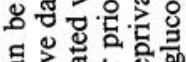

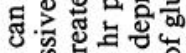

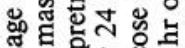

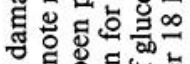

बํㅕㄹ

을.․․․․․․

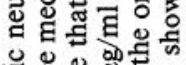

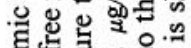

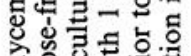

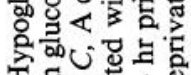

空.

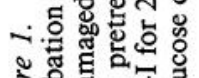

sis

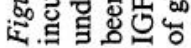


Table 1. Effects of growth factors and calcium removal on neuronal damage induced by glucose deprivation in cultured rat hippocampal and septal neurons

\begin{tabular}{|c|c|c|}
\hline & \multicolumn{2}{|c|}{$\begin{array}{l}\text { Neuronal survival } \\
\text { (\% of initial number) }\end{array}$} \\
\hline & Hippocampus & Septum \\
\hline 0 glucose & $6.2 \pm 2.6$ & $9.84 \pm 2.5$ \\
\hline $5 \mathrm{~mm}$ glucose & $74.82 \pm 9.3^{*}$ & $80.82 \pm 6.7^{*}$ \\
\hline $20 \mathrm{~mm}$ glucose & $77.91 \pm 8.4^{*}$ & $79.38 \pm 7.2^{*}$ \\
\hline $40 \mathrm{~mm}$ glucose & $83.75 \pm 9.4^{*}$ & $87.56+10.2^{*}$ \\
\hline 0 glucose $+100 \mathrm{ng} / \mathrm{ml} \mathrm{IGF-I}$ & $63.49 \pm 7.7^{*}$ & $81.22 \pm 9.8^{*}$ \\
\hline 0 glucose $+100 \mathrm{ng} / \mathrm{ml} \mathrm{IGF-II}$ & $59.89 \pm 6.3^{*}$ & $74.89 \pm 6.7^{*}$ \\
\hline 0 glucose $+100 \mathrm{ng} / \mathrm{ml}$ insulin & $13.38 \pm 4.5$ & $12.31 \pm 4.4$ \\
\hline 0 glucose $+100 \mathrm{ng} / \mathrm{ml} \mathrm{EGF}$ & $14.29 \pm 4.8$ & $11.37 \pm 3.8$ \\
\hline 0 glucose $+0\left[\mathrm{Ca}^{2+}\right]_{0}$ & $75.62 \pm 7.3^{*}$ & $81.48 \pm 5.9^{*}$ \\
\hline 0 glucose $+100 \mathrm{nM}$ CGRP & $3.50 \pm 1.1$ & $4.92 \pm 2.4$ \\
\hline
\end{tabular}

Cultures were incubated in the presence of growth factors for $24 \mathrm{hr}$ prior to exposure to glucose-free medium. Neuronal survival was assessed $18 \mathrm{hr}$ (hippocampus) or $24 \mathrm{hr}$ (septum) following the onset of glucose deprivation. Values represent the mean \pm SEM of determinations made in 4-10 separate cultures per treatment group.

* $p<0.001$, as compared to corresponding values for treatments with 0 glucose, 0 glucose + insulin, 0 glucose + EGF, or 0 glucose + CGRP.

the possibility that the few remaining glia played a role in the action of the IGFs cannot be ruled out.

\section{IGFs protect neurons against hypoglycemic damage by preventing a loss of cellular calcium homeostasis}

Neuronal damage that occurs as the result of ischemia and excitotoxic insults results largely from aberrant elevations in intracellular calcium levels (Choi, 1988; Siesjo et al., 1988; Mattson, 1992). We therefore determined whether hypoglycemic neuronal damage was calcium dependent, and whether IGFs and insulin modified hypoglycemia-induced calcium responses. Hippocampal and septal cultures were incubated in medium lacking extracellular calcium during the period of glucose deprivation in order to prevent calcium influx through the plasma membrane (cf. Mattson et al., 1988). Hypoglycemic damage was significantly reduced in the cultures maintained in the calciumdeficient medium as compared to cultures maintained in the normal medium that contained $2.3 \mathrm{mM} \mathrm{Ca}^{2+}$ (Fig. 3, Table 1). These data indicated that calcium influx was necessary for hypoglycemic damage and suggested that glucose deprivation might result in a loss of neuronal calcium homeostasis. We therefore employed the calcium indicator dye fura-2 to determine the effects of hypoglycemia and growth factors on intraneuronal calcium levels.

Glucose deprivation caused a highly significant three- to fivefold elevation in intraneuronal calcium levels in both hippocampal and septal neurons during 14-16 hr periods (Table 2). IGF-I and IGF-II $(100 \mathrm{ng} / \mathrm{ml})$ each prevented the glucose deprivation-induced intraneuronal calcium increase. EGF did not prevent increase in intraneuronal calcium after glucose deprivation (Table 2). The results demonstrated that a loss of neuronal calcium homeostasis accompanied the hypoglycemic damage, and that IGFs stabilized intracellular calcium levels.

\section{Involvement of excitatory amino acid receptors in} hypoglycemic damage

Ischemic neuronal damage in vivo (Simon ct al., 1984) and in vitro (Goldberg et al., 1987) involves excitatory amino acid
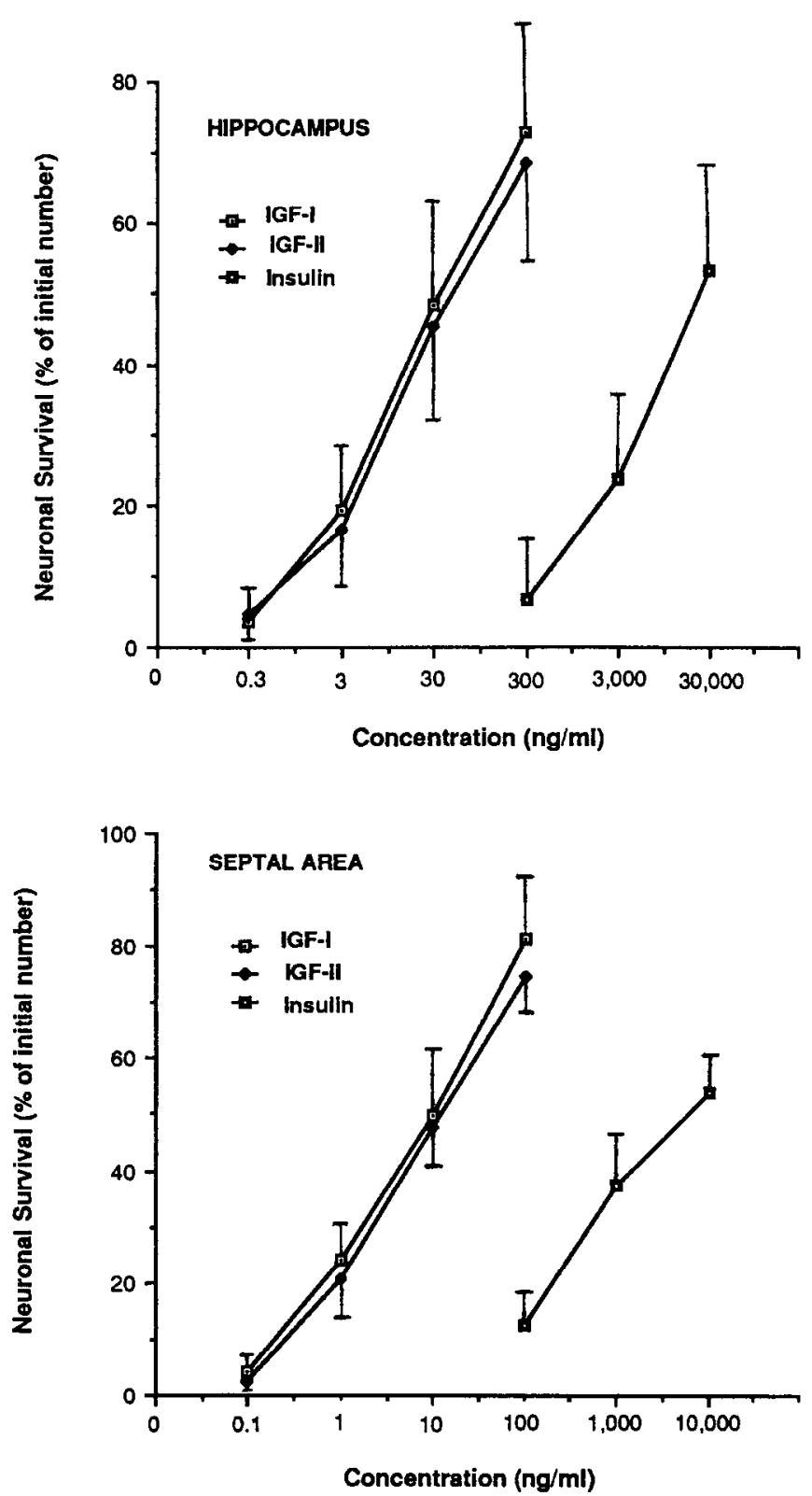

Figure 2. Dose-response curves for the protective effects of growth factors on rat hippocampal (upper) and septal (lower) cultures deprived of glucose. Cultures that had been pretreated for $24 \mathrm{hr}$ with different concentrations of growth factors were exposed to glucose-free medium, and neuronal survival was assessed $18 \mathrm{hr}$ (hippocampal cultures) or 24 hr (septal cultures) later. Values represent the mean and SEM of determinations made in three or four separate experiments.

receptor activation resulting in calcium influx. Since calcium influx was involved in the hypoglycemic damage in the present study, we assessed the involvement of excitatory amino acid receptors in the degenerative process. The NMDA receptor antagonist APV $(100 \mu \mathrm{M})$ and the broad-spectrum glutamate antagonist DGG $(100 \mu \mathrm{M})$ each prevented the elevation in intraneuronal calcium levels and neuronal damage induced by glucose deprivation (Fig. 4). The kainate/AMPA receptor-specific antagonists CNQX $(100 \mu \mathrm{M})$ and DNQX $(100 \mu \mathrm{M})$ did not protect against hypoglycemic damage in either hippocampal or septal cultures. APV, DGG, CNQX, and DNQX alone had no significant effect on neuronal survival in cultures maintained in 


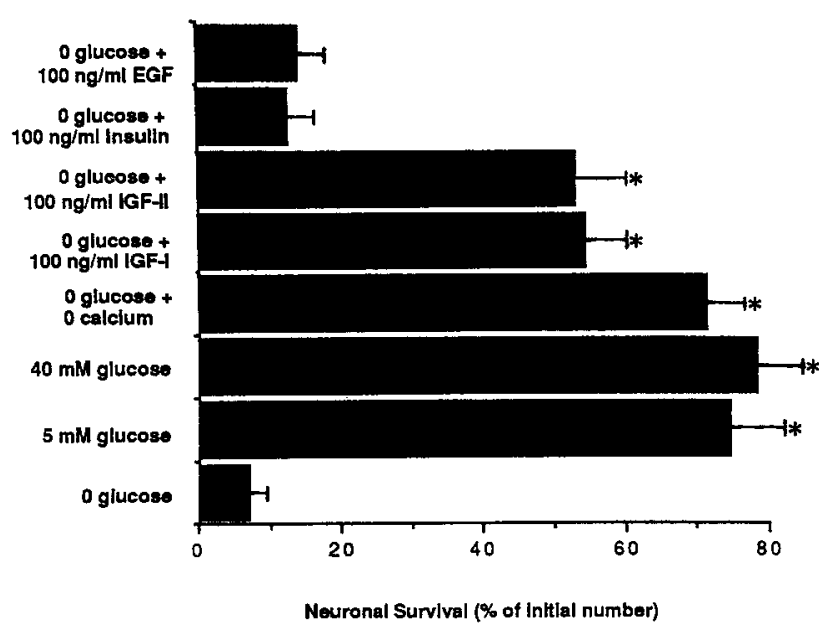

Figure 3. Evidence supporting a direct action of IGF-I and IGF-II in rat hippocampal neurons. Non-neuronal cell division was halted by a $3 \mathrm{~d}$ exposure to $10 \mu \mathrm{M}$ Ara-C. Cultures were then exposed to a growth factor for $24 \mathrm{hr}$ followed by an $18 \mathrm{hr}$ exposure to medium lacking glucose. Values represent the mean and SEM of determinations made in three or four separate cultures. ${ }^{*}, p<0.001$ compared with 0 glucose alone, 0 glucose + insulin, and 0 glucose + EGF.

glucose-containing medium (data not shown; cf. Mattson et al., 1988; Facci et al., 1990).

\section{Effects of calcium channel blockers and kinase inhibitors on hypoglycemic neuronal damage}

Calcium influx through voltage-sensitive channels (Siesjo et al., 1988) and overactivation of protein kinases (Favaron et al., 1990; Mattson, 1991) have been implicated in ischemic/excitotoxic neuronal damage. Previous work indicated that blockers of L-type calcium channels could protect neurons against excitotoxicity (Weiss et al., 1990). It was therefore of interest to determine whether voltage-sensitive calcium channels and/or calcium-dependent protein kinases played a role in glucose deprivation-induced neuronal damage. The dihydropyridine nifedipine $(100 \mu \mathrm{M})$, and verapamil $(10 \mu \mathrm{M})$, did not protect hippocampal neurons against death caused by glucose deprivation (Fig. 5). Similarly, two other L-type calcium channel blockers, diltiazem $(10 \mu \mathrm{M})$ and nimodipine $(20 \mu \mathrm{M})$, were ineffective in protecting hippocampal neurons against hypoglycemic damage (data not shown). These concentrations of calcium channel blockers did not significantly affect neuronal survival in hippocampal cultures incubated in the presence of glucose $(n=4$ separate cultures). Similar results were obtained in septal cultures with these calcium channel blockers (data not shown). Taken together with the data above, these results indicated that calcium influx was responsible for the hypoglycemic neuronal damage, and that the damaging calcium influx occurred through the NMDA receptor channel and/or through non-L-type channels.

In order to determine whether calcium/calmodulin-dependent protein kinases were involved in the hypoglycemic damage, we employed calmodulin inhibitors that had previously been shown to protect neurons in several different paradigms of neuronal death (Rich and Hollowell, 1990; Mattson, 1991). Flunarizine $(10 \mu \mathrm{M})$ did not afford significant protection against hypoglycemic damage (Fig. 5). Two other calmodulin inhibitors, lidoflazine $(10 \mu \mathrm{M})$ and trifluoperazine (100 nM), also did not
Table 2. IGF-I and IGF-II prevent the increase in intraneuronal free calcium caused by glucose deprivation

\begin{tabular}{lcc} 
& \multicolumn{2}{l}{$\begin{array}{l}\text { Intraneuronal calcium } \\
\text { concentration (nM) }\end{array}$} \\
\cline { 2 - 3 } & \multicolumn{1}{c}{ Hippocampus } & Septum \\
\hline 0 glucose & $346 \pm 23$ & $320 \pm 20$ \\
$5 \mathrm{~mm}$ glucose & $91 \pm 13^{*}$ & $84 \pm 9^{*}$ \\
$20 \mathrm{~mm}$ glucose & $81 \pm 9^{*}$ & $84 \pm 8^{*}$ \\
$40 \mathrm{~mm}$ glucose & $89 \pm 10^{*}$ & $80 \pm 10^{*}$ \\
0 glucose $+100 \mathrm{ng} / \mathrm{ml} \mathrm{IGF-I}$ & $68 \pm 8^{*}$ & $78 \pm 9^{*}$ \\
0 glucose $+100 \mathrm{ng} / \mathrm{ml} \mathrm{IGF-II}$ & $72 \pm 12^{*}$ & $83 \pm 7^{*}$ \\
0 glucose $+100 \mathrm{ng} / \mathrm{ml}$ EGF & $265 \pm 26$ & $324 \pm 17$ \\
0 glucose $+0\left[\mathrm{Ca}^{2+}\right]_{o}$ & $82 \pm 10^{*}$ & $79 \pm 8^{*}$
\end{tabular}

Cultures were incubated in the presence of growth factors for $24 \mathrm{hr}$ prior to exposure to glucose-free medium. Intraneuronal calcium levels were measured after 14-16 hr of incubation in the indicated conditions. Values represent the mean \pm SEM of determinations made in $20-40$ neurons.

${ }^{*} p<0.001$, as compared with cultures maintained in 0 glucose or 0 glucose + EGF.

protect neurons against hypoglycemic injury (data not shown). Since recent evidence indicated that overactivation of protein kinase $\mathrm{C}$ (PKC) can result in neurodegeneration (Favaron et al., 1990; Mattson, 1991), we determined whether the PKC inhibitor $\mathrm{H}-7$ would modify hypoglycemic damage. $\mathrm{H}-7$ ( $5 \mu \mathrm{M})$ did not prevent neuronal damage after $18 \mathrm{hr}$ of glucose deprivation in hippocampal cell cultures (Fig. 5). Flunarazine, lidoflazine, and $\mathrm{H}-7$, at the same concentrations as were added to glucosedeprived cultures, did not significantly affect neuronal survival in hippocampal cultures incubated in the presence of glucose; however, trifluoperazine did cause significant neuronal degeneration (data not shown). These data indicate that blockade of calcium/calmodulin-dependent kinases and PKC will not prevent glucose deprivation-induced neuronal death.

\section{Discussion}

An increasing number of growth factors are being identified that protect central neurons against environmental insults. Previous work demonstrated protective effects of basic fibroblast growth factor (bFGF) and NGF against physical, ischemic, and/or excitotoxic damage (Hefti et al., 1985; Anderson et al., 1988; Mattson et al., 1989; Cheng and Mattson, 1991). The present data demonstrated the potent protective effect of IGFs against hypoglycemic damage in hippocampal and scptal cell cultures. Furthermore, we provided evidence that the neuroprotective action of IGFs results from their ability to stabilize neuronal calcium homeostasis. Since central neurons are particularly vulnerable to ischemic insults, these data suggest that IGF may play a neuroprotective role under conditions of reduced energy supply.

The protective effects of IGFs and insulin against glucose deprivation were concentration dependent and specific. Both IGF-I and IGF-II were effective in reducing neuronal death at concentrations $1-3 \mathrm{ng} / \mathrm{ml}$ (approximately $150-450 \mathrm{pm}$ ), with half-maximally effective concentration of approximately $20 \mathrm{ng} /$ $\mathrm{ml}$ (approximately $3 \mathrm{nM}$ ). The dose-response curves for the two IGFs were remarkably similar. In contrast, insulin was only effective in protecting neurons against hypoglycemic damage when administered at levels 100-1000-fold greater than the IGFs (1-3 $\mu \mathrm{g} / \mathrm{ml}$; approximately $200-500 \mathrm{~nm}$ ). These data are consistent with the possibility that the protective effect of insulin 


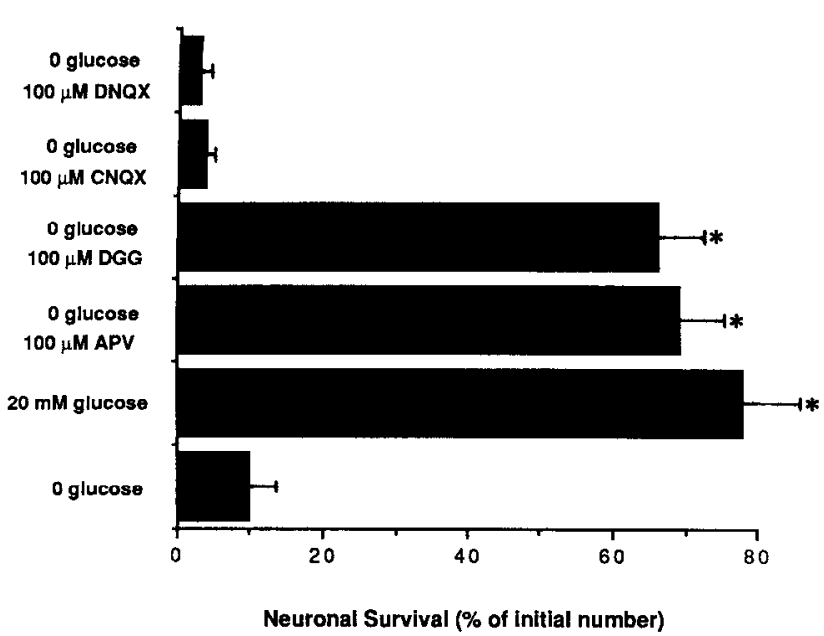

Figure 4. Effects of NMDA and non-NMDA receptor antagonists on hippocampal neuronal death due to glucose deprivation. Cultures were exposed to the indicated treatments and neuronal survival was assessed $18 \mathrm{hr}$ following the onset of glucose deprivation. APV is an NMDA receptor-specific antagonist, CNQX and DNQX are non-NMDA receptor-specific antagonists, and DGG is a broad-spectrum glutamate receptor antagonist. Values represent the mean and SEM of determinations made in three or four separate experiments. ${ }^{*}, p<0.001$ compared to 0 glucose, 0 glucose + CNQX, and 0 glucose + DNQX.

was mediated by IGF-I receptor since previous studies have demonstrated an approximately 1000-fold lower affinity of insulin (as compared to IGFs) for IGF-I receptor (Ullrich et al., $1985,1986)$. Since insulin does not appear to hind to IGF-II receptor (Baskin et al., 1988), the growth or protective effects of insulin on CNS cells may be due to its binding to the IGF-I receptor. Autoradiographic studies indicated that there are IGF-I and IGF-II receptors, but no insulin receptors, in the hippocampus (Bohanon et al., 1988; Lesniak et al., 1988). IGF-I receptors are concentrated in strata radiata and oriens, particularly in region CA3, suggesting that they may be present on pyramidal neurons. In situ hybridization studies indicated that insulin and IGF-I receptor mRNAs are present in hippocampus (Baron-Van Evercooren et al., 1991). We found that IGF-I and IGF-II were equipotent in protecting neurons against hypoglycemia. When taken together with the fact that IGF-I has a higher affinity for IGF-I receptors than does IGF-II (and vice versa), our data suggest that hippocampal and septal neurons have both IGF-I and IGF-II receptors.

Rat hippocampal cultures contain essentially all non-cholinergic neurons, whereas septal cultures contain a large population of cholinergic neurons (Hefti et al., 1989). Previous studies showed that IGFs and insulin elevated ChAT activity in septal cultures and dopamine uptake in mesencephalic cultures (Knusel et al., 1990). No data were previously available concerning actions of IGFs and insulin in hippocampal neurons. Our data indicate that IGFs are likely to influence a rather large number of neuronal types in the brain. As with the IGFs, bFGF has been shown to support cell survival and neurite outgrowth in cultured neurons (including cholinergic and non-cholinergic) from various brain regions (Morrison et al., 1986; Walicke et al., 1986; Unsicker et al., 1987; Hatten et al., 1988; Walicke, 1988). Intracerebral administration of bFGF prevents degencrative changes of lesioned cholincrgic neurons of the basal forebrain (Anderson et al., 1988). In contrast to IGFs and FGF,

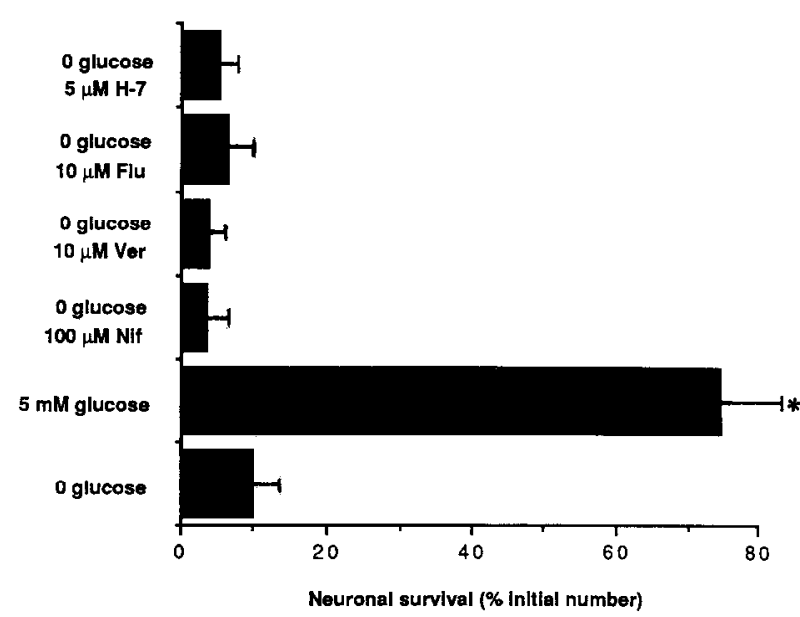

Figure 5. Effects of calcium channel blockers and kinase inhibitors on hippocampal neuronal death resulting from glucose deprivation. Inhibitors were included in the culture medium during an $18 \mathrm{hr}$ period of glucose deprivation. Inhibitors were nifedipine (Nif), verapamil (ver), flunarizine (Flu), and H-7. Values represent the mean and SEM of determinations made in three or four separate cultures. Nifedipine, verapamil, flunarizine, and $\mathrm{H}-7$ did not protect against the neuronal death $(p>0.05)$.

the biological actions of NGF in the CNS seem to be limited to certain populations of primarily cholinergic neurons (Thoenen et al., 1987; Hefti et al., 1989; Snider and Johnson, 1989). On the other hand, we recently found that NGF and bFGF protected both rat hippocampal and human cortical neurons against hypoglycemic damage (Cheng and Mattson, 1991), indicating that NGF, in addition to actions on peripheral neurons and central cholinergic neurons, can also directly affect central non-cholinergic neurons. Taken together, the available data indicate that IGF-I and IGF-II, as well as bFGF and probably NGF, affect both cholinergic and non-cholinergic central neurons. The extent to which the signal transduction systems for these different growth factors are different or overlapping remains to be determined.

Insulin and IGFs are known to affect glial cells (Lenoir and Honegger, 1983; Avola et al., 1988). Glial cells, in turn, are known to provide trophic support for neurons (Mattson and Rychlik, 1990). In the present study, however, treatment of the cultures with Ara-C to prevent cellular proliferation only slightly reduced the neuroprotective effects of IGFs. This suggests that the neuroprotective effects of IGFs were mainly the results of direct actions on the hippocampal and septal neurons, although a role for glia was not completely ruled out.

The mechanism of hypoglycemic neuronal damage is not completely understood, but appears to involve a loss of neuronal calcium homeostasis. In support of this mechanism, we found that removal of extracellular calcium prevented hypoglycemic damage. Contributing to the loss of calcium homeostasis was calcium influx triggered by activation of NMDA receptors since APV, a specific blocker of NMDA-type calcium channels, significantly reduced hypoglycemic damage. This possibility is consistent with previous data obtained in mouse cortical and rat cerebellar cultures wherein hypoglycemic damage was reduced by NMDA receptor antagonists (Monyer et al., 1989; Facci et al., 1990). Non-NMDA receptor antagonists (CNQX and DNQX) did not reduce hypoglyccmic neuronal damage in the present study, indicating that activation of non-NMDA recep- 
tors is probably not necessary for hypoglycemic damage. In addition, dihydropyridine blockers of L-type calcium channels (nimodipine and nifedipine), as well as verapamil and diltiazem did not reduce hypoglycemic damage, indicating that calcium influx through the L-type channel was not a major factor contributing to the loss of calcium homeostasis. Taken together, these findings suggest that calcium influx through the NMDA receptor channel was a major contributor to the degenerative effects of glucose deprivation. However, we cannot yet rule out the possibility that calcium influx through non-L-type calcium channels plays a role in hypoglycemic neuronal damage, since a substantial portion of high-threshold calcium current is resistant to dihydropyridines and $\omega$-conotoxin (Regan et al., 1991).

Both IGF-I and IGF-II prevented hypoglycemia-induced loss of neuronal calcium homeostasis. The specific system(s) for calcium homeostasis affected by IGFs is not clear. Previous work provided evidence that neuronal growth factors can stabilize neuronal calcium homeostasis. For example, NGF influenced the expression of calcium channels and calcium-extruding systems in PC1 2 cells (Takahashi et al., 1985; Chalazonitis et al., 1987; Masiakowski and Shooter, 1988; Streit and Lux, 1990). In addition, bFGF protected cultured rat hippocampal neurons against excitatory amino acid neurotoxicity (Mattson et al., 1989). The protective effect of bFGF is mediated at least in part by a suppression of the expression of an NMDA receptor protein by this growth factor (Mattson et al., 1991; Michaelis et al., 1991). In addition, bFGF may enhance the ability of neurons to reduce intracellular calcium levels following an excitatory challenge (Mattson and Rychlik, 1990). In a recent related study we found that NGF and bFGF protected rat hippocampal and human cerebral cortical neurons against neuronal damage caused by glucose deprivation (Cheng and Mattson, 1991). In the latter study we found that both NGF and bFGF prevented the loss of neuronal calcium homeostasis that normally mediated hypoglycemic damage. Growth factors may also stabilize intracellular calcium levels in peripheral neurons. For example, in cultured sympathetic neurons NGF appears to influence neuronal systems for calcium homeostasis and these effects of NGF are correlated with its trophic action (Koike and Tanaka, 1991). Taken together, the available data suggest that a general feature of growth factor action may be to stabilize neuronal intracellular free calcium levels.

Overactivation of protein kinases has been suggested to be involved in the neuronal damage that occurs in a number of neurodegenerative conditions. For example, ischemic brain damage is associated with altered PKC activity (Louis et al., 1988), and administration of a PKC inhibitor was found to reduce ischemic damage (Joo et al., 1989). Overactivation of calcium/calmodulin-dependent kinase(s) and PKC have been implicated in the neurofibrillary degeneration that occurs in Alzheimer's disease and related disorders (Mattson, 1990, 1991). In the present study, calmodulin inhibitors (flunarizine, lidoflazine, and trifluoperazine) and the PKC inhibitor $\mathrm{H}-7$ did not protect hippocampal or septal neurons against hypoglycemic damage. Thus, we were not able to provide evidence supporting a role for calmodulin-dependent protein kinases or PKC in hypoglycemic damage. These data suggest that these calcium-regulated kinases may not be involved in hypoglycemic damage. However, since we did not directly assess kinase activity, we cannot rule out the possibility that the kinase inhibitors used did not completely block kinase activities. Clearly, further work will be required to understand the specific events triggered by glucose deprivation that lead to a loss of neuronal calcium homeostasis and cell death.

The protective effects of IGFs against hypoglycemic damage demonstrated here are consistent with the possibility that IGFs play a neuroprotective role in vivo. In the developing nervous system IGFs may play a role in determining which neurons survive during the period of naturally occurring neuronal death, and in the process of synaptic organization. From a pathological standpoint, IGFs may also play a role in preventing neuronal death. The hippocampus and septal area are brain regions that are particularly vulnerable in acute (e.g., stroke) and chronic (e.g., Alzheimer's disease) neurodegenerative disorders. The present data may therefore have implications for approaches to preventing neuronal damage in these disorders.

\section{References}

Aizenman Y, DeVellis J (1987) Brain neurons develop in a serum and glial free environment: effects of transferrin, insulin, insulin-like growth factor I and thyroid hormone neuronal survival, growth and differentiation. Brain Res 406:32-42.

Anderson KJ, Dam D, Lee S, Cotman CW (1988) Basic fibroblast growth factor prevents death of lesioned cholinergic neurons in vivo. Nature 332:360-361.

Araujo DM, Lapchak PA, Collier B, Chabot JG, Quirion R (1989) Insulin-like growth factor-I (somatomedin-C) receptors in the rat brain: distribution and interaction with the hippocampal cholincrgic systcm. Brain Res 484:130-138.

Avola R, Condorelli DF, Surrentino S, Turpeenoja L, Costa A, Giuffrida Stella AM (1988) Effect of epidermal growth factor and insulin on DNA, RNA, and cytoskeletal protein labeling in primary rat astroglial cell cultures. J Neurosci Res 19:230-238.

Ballotti R, Nielsen FC, Pringle N, Kowalski A, Richardson WD, Van Obberghen A, Gammeltoft S (1987) Insulin-like growth factor I in cultured rat astrocytes: expression of the gene, and receptor tyrosine kinase. EMBO J 6:3633-3639.

Baron-Van Evercooren A, Olichon-Berthe C, Kowalski A, Visciano G, Van Obberghen E (1991) Expression of IGF-I and insulin receptor gene in the rat central nervous system: a developmental, regional, and cellular analysis. J Neurosci Res 28:244-253.

Baskin DG (1987) Insulin in the brain. Annu Rev Physiol 49:335347.

Baskin DG, Wilcox BJ, Figlewicz DP, Dorsa DM (1988) Insulin and insulin-like growth factors in the CNS. Trends Neurosci 11:103-111.

Bhat N (1983) Insulin dependent neurite outgrowth in cultured embryonic mouse brain cells. Dev Brain Res 11:315-318.

Binoux M, Hossenlop C, Lassare C, Hardouin N (1981) Production of insulin-like growth factors and their carrier by rat pituitary gland and brain explants in culture. FEBS Lett 124:178-184.

Bohanon NJ, Corp ES, Wilcox B, Figlewicz DP, Dorsa DM, Baskin DG (1988) Localization of binding sites for insulin-like growth factor I (IGF-I) in the rat brain by quantitative autoradiography. Brain Res 444:205-213.

Burgess SK, Jacobs S, Cuatrecasas P, Sahyoun N (1987) Characterization of a neuronal subtype of insulin-like growth factor I receptor. J Biol Chem 262:1618-1622.

Chalazonitis A, Peterson ER, Crain SM (1987) Nerve growth factor regulates the action potential duration of mature sensory neurons. Proc Ni.tl Acad Sci USA 84:289-293.

Cheng B, Mattson MP (1991) NGF and bFGF protect rat hippocampal and human cortical neurons against hypoglycemic damage by stabilizing calcium homeostasis. Neuron 7:1031-1041.

Choi DW (1988) Glutamate neurotoxicity and diseases of nervous system. Neuron 1:623-634.

Czech MP (1985) The nature and regulation of insulin receptor: structure and function. Annu Rev Physiol 47:357-381.

Davies AM, Thoenen H, Barde YA (1986) The response of chick sensory neurons to brain-derived neurotropic factor. J Neurosci 6: 1897-1904.

Drago J, Murphy M, Carroll SM, Harvey RP, Bartlett PF (1991) Fibroblast growth factor-mediated proliferation of central nervous system precursors depends on endogenous production of insulin-like growth factor I. Proc Natl Acad Sci USA 88:2199-2203. 
Ebina Y, Ellis L, Jarnagin K, Edery M, Graf L, Clauser E, Ou JH, Masiarz F, Kan YW, Goldfine ID, Roth RA, Rutter WJ (1985) The human insulin receptor cRNA: the structural basis for hormone-activated transmembrane signalling. Cell 40:747-758.

Facci L, Lcon A, Skaper SD (1990) Hypoglycemic neurotoxicity in vitro: involvement of excitatory amino acid receptors and attenuation by monosialoganglioside GM1. Neuroscience 37:709-716.

Favaron M, Manev $H$, Siman $R$, Bertolino M, Szekely AM, DeErausquin G, Guidotti A, Costa E (1990) Down-regulation of protein kinase $C$ protects cerebellar granule neurons in primary culture from glutamate-induced neuronal death. Proc Natl Acad Sci USA 87: 1983-1987.

Froesch ER, Schmid C, Schwander J, Zapf J (1985) Actions of insulinlike growth factors. Annu Rev Physiol 47:443-467.

Garofalo RS, Rosen OM (1989) Insulin and insulin-like growth factor I (IGF-I) receptors during central nervous system development: expression of two immunologically distinct IGF-I receptor beta subunits. Mol Cell Biol 9:2806-2817.

Goldberg MP, Weiss JH, Pham P-C, Choi DW (1987) N-methyl-Daspartate receptors mediate hypoxic neuronal injury in cortical culture. J Pharmacol Exp Ther 243:784-791.

Grynkiewicz G, Poenie M, Tsien RY (1985) A new generation of calcium indicators with greatly improved fluorescence properties. J Biol Chem 260:3440-3450.

Hartikka J, Hefti F (1988) Development of septal cholinergic neurons in culture: plating density and glial cells modulate effects of NGF on survival, fiber growth, and expression of transmitter-specific enzymes. J Neurosci 8:2967-2985.

Haselbacher GK, Schwab ME, Pasi A, Humbel RE (1985) Insulinlike growth factor II (IGF-II) in human brain: regional distribution of IGF-II and higher molecular mass forms. Proc Natl Acad Sci USA 82:2153-2157.

Hatten ME, Lynch M, Rydel RE, Sanchez J, Joseph-Silverstein J, Moscatelli D, Rifkin D (1988) In vitro neurite extension by granule neurons is dependent upon astroglial-derived fibroblast growth factor. Dev Biol 125:280-289.

Havrankova J, Schmechel D, Roth J, Brownstein M (1978) Identification of insulin in rat brain. Proc Natl Acad Sci USA 75:5737-5741.

Hefti F, Hartikka J, Eckenstein F, Gnahn H, Heumann R, Schwab M (1985) Nerve growth factor (NGF) increases choline acetyltransferase but not survival or fiber outgrowth of cultured fetal septal cholinergic neurons. Neuroscience 14:55-68.

Hefti F, Hartikka J, Knusel B (1989) Function of neurotrophic factors in the adult and aging brain and their possible use in the treatment of neurodegenerative diseases. Neurobiol Aging 10:515-533.

Hill JM, Lesniak MA, Pert CB, Roth J (1986) Autoradiographic localization of insulin receptors in rat brain: prominence in olfactory and limbic areas. Neuroscience 17:1127-1138.

Humbel RE (1984) Insulin-like growth factors, somatomedins and multiplication stimulating activity. In: Hormonal proteins and peptides, Vol 12 (Li CH, ed), p 57. Orlando, FL: Academic.

Joo F, Tosaki A, Olah Z, Koltai M (1989) Inhibition by $\mathrm{H}-7$ of the protein kinase $C$ prevents formation of brain edema in SpragueDawley CFY rats. Brain Res 490:141-143.

Kater SB, Mattson MP, Cohan C.S, Connor JA (1988) Calcium regulation of the neuronal growth cone. Trends Neurosci 11:315-321.

Knusel B, Michel PP, Schwaber JS, Hefti F (1990) Selective and nonselective stimulation of central cholinergic and dopaminergic development in vitro by nerve growth factor, basic fibroblast growth factor, epidermal growth factor, insulin and the insulin-like growth factors I and II. J Neurosci 10:558-570.

Koike T, Tanaka S (1991) Evidence that nerve growth factor dependence of sympathetic neurons for survival in vitro may be determined by levels of cytoplasmic free $\mathrm{Ca}^{2+}$. Proc Natl Acad Sci USA 88:38923896.

Kyriakis JM, Hausman RE, Peterson SW (1987) Insulin stimulates choline acetyltransferase activity in cultured embryonic chicken retina neurons. Proc Natl Acad Sci USA 84:7463-7467.

Lenoir D, Honegger P (1983) Insulin-like growth factor I (IGF-I) stimulates DNA synthesis in fetal rat brain cell cultures. Dev Brain Res 7:205-213.

Lesniak MA, Hill JM, Kiess W, Rojeski M, Pert CB, Roth J (1988) Receptors for insulin-like growth factors I and II: autoradiographic localization in rat brain and comparison to receptors for insulin. Endocrinology 123:2089-2099.
Louis J-C, Magal E, Yavin E (1988) Protein kinase C alterations in fetal rat brain after global ischemia. J Biol Chem 263:19282-19285.

Lynch G, Larson J, Kelso S, Barrioneuevo G, Schottler F (1983) Intracellular injections of EGTA block induction of hippocampal long term potentiation. Nature 305:719-721.

Masiakowski P, Shooter EM (1988) Nerve growth factor induces the genes for two proteins related to family of calcium-binding proteins in PC12 cells. Proc Natl Acad Sci USA 85:1277-1281.

Mattson MP (1990) Antigenic changes similar to those seen in neurofibrillary tangles are elicited by glutamate and $\mathrm{Ca}^{2+}$ influx in cultured hippocampal neurons. Neuron 4:105-117.

Mattson MP (1991) Evidence for the involvement of protein kinase $C$ in neurodegenerative changes in cultured human cortical neurons. Exp Neurol 112:95-103.

Mattson MP (1992) Calcium as sculptor and destroyer of neural circuitry. Exp Gerontol 27:29-49.

Mattson MP, Kater SB (1988) Isolated hippocampal neurons in cryopreserved long-term cultures: development of neuroarchitecture and sensitivity to NMDA. Int J Dev Neurosci 6:439-452.

Mattson MP, Rychlik B (1990) Glia protect hippocampal neurons against excitatory amino acid-induced degeneration: involvement of fibroblast growth factor. Int J Dev Neurosci 8:399-415.

Mattson MP, Dou P, Kater SB (1988) Outgrowth-regulating actions of glutamate in isolated hippocampal pyramidal neurons. J Neurosci 8:2087-2100.

Mattson MP, Murrain M, Guthrie PB, Kater SB (1989) Fibroblast growth factor and glutamate: opposing actions in the generation and degeneration of hippocampal neuroarchitecture. J Neurosci 9:37283740 .

Mattson MP, Wang H, Michaelis EK (1991) Developmental expression, compartmentalization, and possible role in excitotoxicity of a putative NMDA receptor protein in cultured hippocampal neurons. Brain Res 565:94-108.

Mendlesohn LG (1987) Visualization of IGF-II receptors in rat brain In: Insulin, insulin-like growth factors, and their receptors in the central nervous system (Raizada MK, Phillips MI, LeRoith D, eds), pp 269-275. New York: Plenum.

Michaelis EK, Wang H, Mattson MP (1991) NMDA receptor protein in cultured hippocampal neurons: developmental expression, relation to excitotoxicity, and regulation by basic FGF. Soc Neurosci Abstr $17: 74$

Mill JF, Chao MV, Ishii DN (1985) Insulin, insulin-like growth factor II, and nerve growth factor effects on tubulin mRNA levels and neurite formation. Proc Natl Acad Sci USA 82:7126-7130.

Monyer H, Goldberg MP, Choi DW (1989) Glucose deprivation neuronal injury in cortical culture. Brain Res 483:347-354.

Morgan DO, Jarnagin K, Roth RA (1986) Purification and characterization of the receptor for insulin-like growth factor I. Biochemistry $25 \cdot 5560-5564$

Morgan DO, Edman JC, Standring DN, Fried VA, Smith MC, Roth RA, Rutter WJ (1987) Insulin-like growth factor II receptor as a multifunctional binding protein. Nature 329:301-307.

Morrison RS, Sharma A, DeVellis J, Bradshaw RA (1986) Basic fibroblast growth factor supports the survival of cerebral cortical neurons in primary culture. Proc Natl Acad Sci USA 83:7537-7541.

Raizada MK, Stamler JF, Quinlan JT, Landas S, Phillips MI (1982) Identification of insulin receptor-containing cells in primary cultures of rat brain. Cell Mol Neurobiol 2:47-52.

Raizada MK, Shemer J, Judkins JH, Clarke DW, Masters BA, LeRoith D (1988) Insulin receptor in the brain: structural and physiological characterization. Neurochem Res 13:297-303.

Rechler MM, Nissley SP (1985) The nature and regulation of the receptors for insulin-like growth factors. Annu Rev Physiol 47:425442.

Recio-Pinto E, Rechter MM, Ishii DN (1986) Effects of insulin, insulin-like growth factor-II and nerve growth factor on neurite formation and survival in cultured sympathetic and sensory neurons. J Neurosci 6:1211-1219.

Regan LJ, Sah DWY, Bean BP (1991) $\mathrm{Ca}^{2+}$ channels in rat central and peripheral neurons: high threshold current resistant to dihydropyridine blockers and omega-conotoxin. Neuron 6:269-280.

Rich KM, Hollowell JP (1990) Flunarazine protects neurons from death after axotomy or NGF deprivation. Science 248:1419-1421.

Rinderknecht E, Humbel RE (1976) Polypeptides with nonsuppressible insulin-like and cell growth promoling activity in human serum: 
isolation, chemical characterization and some biological properties. Proc Natl Acad Sci USA 73:2365-2369.

Rinderknecht E, Humbel RE (1978a) The amino acid sequence of human insulin-like growth factor I and its structural homology with proinsulin. J Biol Chem 253:2769-2776.

Rinderknecht E, Humbel RE (1978b) Primary structure of human insulin-like growth factor II. FEBS Lett 89:283-286.

Rotwein P, Burgess SK, Milbrandt JD, Krause JE (1988) Differential expression of insulin-like growth factor genes in rat central nervous systcm. Proc Natl Acad Sci USA 85:265-269.

Sara VR, Hall K (1990) Insulin-like growth factors and their binding proteins. Physiol Rev 70:591-614.

Sara VR, Hall K, Von Holtz H, Humber R, Sjogren B, Wetterberg L (1982) Evidence for the presence of specific receptors for insulin-like growth factors 1 (IGF-I) and 2 (IGF-II) and insulin throughout the adult human brain. Neurosci Lett 34:39-44.

Sara VR, Carlsson-Skwirut C, Andersson C, Hall K, Sjogren B, Holmgren A, Jurnvall H (1986) Characterization of somatomedins from human fetal brain: identification of a variant form of insulin-like growth factor I. Proc Natl Acad Sci USA 83:4904-4907.

Siesjo BK, Bengtsson F, Grampp W, Theander S (1988) Calcium, excitotoxins, and neuronal death in the brain. Ann NY Acad Sci 568: 234-251.

Simon RP, Swan JH, Griffiths T, Meldrum BS (1984) Blockade of $\mathrm{N}$-methyl-D-aspartate receptors may protect against ischemic damage in the brain. Science 226:850-852.

Snider WD, Johnson EM (1989) Neurotrophic molecules. Ann Neuron 26:489-506.

Streit J, Lux HD (1990) Calcium current inactivation during nerve growth factor-induced differentiation of PC12 cells. Pfluegers Arch 416:368-374.

Takahashi M, Tsukui $H$, Hatanaka $H$ (1985) Neuronal differentiation of $\mathrm{Ca}^{2+}$ channel by nerve growth factor. Brain Res 341:381-384.

Thoenen H, Bandtlow C, Heumann R (1987) The physiological function of nerve growth factor in the central nervous system: comparison with the periphery. Rev Physiol Biochem Pharmacol 109:145-178.
Ullrich A, Bell JR, Chen EY, Herrera R, Petruzzelli LM, Dull TJ, Gray A, Coussens L, Liao YC, Tsubokawa M, Mason A, Seeburg PH, Grunfeld C, Rosen OM, Ramachandran J (1985) Human insulin receptor and its relationship to the tyrosine kinase family of oncogenes. Nature 313:756-761.

Ulirich A, Gray A, Tam AW, Yang-Feng T, Tsubokawa M, Collins C, Henzel W, Le Bon T, Kathuria S, Chen E, Jacobs S, Francke U, Ramachandran J, Fujita-Yamaguchi Y (1986) Insulin-like growth factor I receptor primary structure: comparison with insulin receptor suggests structural determinants that define function specificity. EMBO J 5:2503-2512.

Unsicker K, Reichert-Preibsch H, Schmidt R, Pettmann B, Labourdette G, Sensenbrenner M (1987) Astroglial and fibroblast growth factors have neurotrophic functions for cultured peripheral and central nervous system neurons. Proc Natl Acad Sci USA 84:5459-5463.

Waldbillig RJ, LeRoith D (1987) Insulin receptors in the peripheral nervous system: a structural and functional analysis. Brain Res 409: 215-220.

Walicke PA (1988) Basic and acidic fibroblast growth factors have trophic effects on neurons from multiple CNS regions. J Neurosci 8: 2618-2627.

Walicke P, Cowan WM, Ueno N, Baird A, Guillemin R (1986) Fibroblast growth factor promotes survival of dissociated hippocampal neurons and promotes neurite extension. Proc Nall Acad Sci USA 83:3012-3016.

Weiss JH, Hartley DM, Koh J, Choi DW (1990) The calcium channel blocker nifedipine attenuates slow excitatory amino acid neurotoxicity. Science 247:1474-1476.

Weyhenmeyer JA, Fellows RE (1983) Presence of immunoreactive insulin in neurons cultured from fetal rat brain. Cell Mol Neurobiol 3:81-86.

Young WS (1986) Periventricular hypothamalic cells in the rat brain contain insulin mRNA. Neuropeptides 8:93-97. 